\title{
Efektifitas sistem informasi berbasis online dalam pengurusan vaksin calon keberangkatan jemaah umrah di kantor kelas II pekanbaru
}

\author{
Bayu Febriadi \\ Program Studi Sistem Informasi Fakultas Ilmu Komputer Universitas Lancang Kuning \\ Jl. Yos Sudarso KM. 8 Rumbai, Pekanbaru, Riau, telp. 08117532015 \\ e-mail: bayu.febriadi@ac.id
}

\begin{abstract}
Abstrak
Seiring dengan perkembangan teknologi yang begitu pesat, sistem informasi berbasis komputer sangat berpengaruh pesat dalam dunia kerja, begitu juga halnya sistem informasi berbasis web dimanfaatkan sebagai sarana peningkatan informasi. Pemanfaatan tersebut akan mempermudah suatu pekerjaan seperti halnya pengolahan data lebih cepat, keputusan yang akan diambil lebih tepat, menghemat waktu dan biaya. Selain itu, sistem informasi yang berbasis web juga dapat menjadi sarana promosi yang efesien dan sumber informasi yang dapat diakses oleh pengguna internet yang semakin lama semakin luas. Pada kantor Kesehatan Pelabuhan Pekanbaru selalu dihadapi dengan kendala antri atau lama dalam pengurusan vaksin keberangkatan calon Jemaah umrah, karena dalam pengurusan vaksin pada kantor Kesehatan Pelabuhan pekanbaru belum adanya sistem terkomputerisasi, sehingga hal ini memperlambat kinerja kantor Kesehatan Pelabuhan pekanbaru, begitupun bagi calon Jemaah umrah yang selalu tidak puas dalam pelayanan vaksin untuk keberangkatan calon jemaah umrah karena terlalu lama dalam pemprosesan hasil dari analisa vaksin keberangkatan calon Jemaah umrah. Adapun metode yang digunakan dengan mengumpulkan data-data yang ada dan menganalisa permasalahan dalam pengurusan vaksin dengan membangun sebuah sistem berbasis web. Tujuan umum dari penelitian ini memberi suatu efisiensi atau peningkatan dalam pengolahan data yang berbasis web sehingga membantu kegiatan kantor Kesehatan Pelabuhan Pekanbaru, tujuan khususnya dimana calon jemaah umrah bisa melihat jadwal vaksin nya dan bisa melihat pengumuman yang lebih cepat dan tepat tanpa harus datang ke kantor Kesehatan Pelabuhan Pekanbaru, hanya dengan mengakses internet dan mengakses website Kantor Kesehatan Pelabuhan pekanbaru dengan mudah, tidak memerlukan waktu yang lama.
\end{abstract}

Kata kunci: Vaksin, Web, Kesehatan Pelabuhan Pekanbaru.

\begin{abstract}
Along with the development of technology so fast, computer-based information systems are very influential rapidly in the world of work, as well as web-based information system used as a means of improving information. This utilization will simplify the job as well as faster data processing, decision to be taken more precisely, saving time and costs. In addition, web-based information system also can be an efficient means of promotion and resources that can be accessed by Internet users are becoming increasingly widespread. At the office of the Port Health Pekanbaru always faced with constraints queue or longer in the administration of the vaccine departures candidate Jemaah umrah, because the maintenance of the vaccine in the office of the Port Health pekanbaru the absence of a computerized system, so it slows down the performance of the office of Port Health pekanbaru, as well as for prospective Jemaah Umrah not always satisfied in the service of a vaccine for the departure of Umrah pilgrims candidate from too long in processing the results of the analysis of vaccine candidates Jemaah departure umrah. The method used to collect data and analyze the problems that exist in the administration of the vaccine by developing a web-based system. The general objective of this
\end{abstract}


study gives an efficiency or an increase in data processing, web-based so that assist the office of the Port Health Pekanbaru, the specific objectives which prospective Umrah pilgrims could see the vaccine schedule her and could see the announcement of a faster and accurately without having to come to the office of Health port of Pekanbaru, simply by accessing the internet and access websites port Health Office Pekanbaru is easy, does not require a long time

Keywords: Vaccine, Web, Kesehatan Pelabuhan Pekanbaru

\section{Pendahuluan}

Seiring dengan perkembangan teknologi yang begitu pesat, sistem informasi berbasis komputer sangat berpengaruh pesat dalam dunia kerja, begitu juga halnya sistem informasi berbasis web dimanfaatkan sebagai sarana peningkatan informasi. Pemanfaatan tersebut akan mempermudah suatu pekerjaan seperti halnya pengolahan data lebih cepat, keputusan yang akan diambil lebih tepat, menghemat waktu dan biaya. Selain itu, sistem informasi yang berbasis web juga dapat menjadi sarana promosi yang efesien dan sumber informasi yang dapat diakses oleh pengguna internet yang semakin lama semakin luas. Dimana pemanfaatan sistem informasi berbasis komputer sangat membantu dalam kegiatan sehari-hari. Pada kantor Kesehatan Pelabuhan Kelas II Pekanbaru belum adanya suatu sistem terintegrasi dalam pelayanan, sehingga selalu dihadapi dengan kendala antri atau lama dalam pengurusan vaksin keberangkatan calon jemaah umrah, ditambah lagi dengan keterbatasan jumlah petugas operator, sehingga hal ini memperlambat kinerja kantor Kesehatan Pelabuhan Kelas II Pekanbaru, begitupun bagi calon jemaah umrah yang selalu tidak puas dalam pelayanan vaksin untuk keberangkatan calon jemaah umrah karena terlalu lama dalam pendaftaran, pengurusan, syarat dan analisa vaksin keberangkatan calon jemaah umrah. Berdasarkan latar belakang uraian diatas, maka dapat dirumuskan beberapa masalah sebagai berikut.

"Bagaimana membangun sistem aplikasi Pelayanan Berbasis web pada Kantor Kesehatan Pelabuhan Kelas II Pekanbaru guna mempermudah dalam penyampaian informasi dan meningkatkan mutu layanan kepada masyarakat Kota Pekanbaru khusunya dalam pengurusan vaksin calon jemaah umrah?"

Setelah dilakukan penelitan ke Kantor Kesehatan pelabuhan Pekanbaru penulis menemukan beberapa permasalahan yang harus segera dibenahi diantaranya.

1. Sering terjadi kendala keterlambatan dalam pelayanan vaksin karena pencatatan data dicatat dalam buku secara manual, dan belum adanya penyimpanan data koputerisasi sehingga hal ini sangat menggangu dalam pelayanan vaksin calon Jemaah umrah.

2. Belum adanya media informasi sebagai media sarana komunikasi, khususnya dalam pelayanan pengurusan vaksin, sementara sudah tersedia jaringan komputer yang bisa digunakan secara global.

3. Belum adanya pengolahan pelayanan data elektronik sementara pengadaan komputer dan sumber daya sudah ada, sehingga data olah harian kegiatan masih disimpan dalam bentuk lembaran kertas dimana hal ini mungkin tidak efisien untuk pengolahan data yang berulangulang apabila suatu saat memerlukan data untuk ditampilkan kembali apabila data ini hilang atau terjadi kerusakan terhadap data ini.

Berkaitan dengan hal tersebut, maka sangat diperlukan adanya, sistem yang dapat membantu semua permasalahan data di atas. Permasalahan berkaitan penting dengan pemberian layanan yang baik kepada masyarakat. Maka diperlukan sebuah bentuk permodelan sistem yang baru. Permodelan ini nantinya akan dikembangkan dalam bentuk sistem yang nantinya bisa diterapkan di Kantor Kesehatan Pelabuhan Pekanbaru.

Adapun Tujuan Umum dari penelitian ini adalah membangun sebuah aplikasi pelayan vaksin berbasis web sebagai media informasi bagi masyarakat, khususnya tentang pengurusan vaksin keberangkatan calon jemaah umrah dimana calon jemaah umrah bisa mendaftar dan 
melihat jadwal pengurusan vaksin hanya cukup dengan mengakses internet dan mengakses website Kantor Kesehatan Pelabuhan Kelas II Pekanbaru dengan mudah, begitu juga untuk melihat pengumuman yang lebih cepat dan tepat dalam pelayanan vaksin keberangkatan calon jemaah umrah. Maka penulis tertarik untuk mengangkat masalah ini menjadi suatu sistem informasi berbasis web.

\section{Metode Penelitian}

\subsection{Tahapan Perancangan Sistem}

Metodologi penelitian untuk merancang aplikasi pelayanan berbasis web dilakukan melalui enam tahapan yaitu (Jogiyanto, 2007):

a. Menentukan requirement sistem pelayanan vaksin berbasis web

b. Identifikasi aktor-aktor yang berperan dan tanggung jawab setiap aktor dalam penyelenggaraan sistem pelayanan vaksin online.

c. Membuat skenario komunikasi yang terjadi pada pelaksanaan pelayanan vaksin online.

d. Menyusun perintah-perintah transaksi yang diperlukan sebagai identifier dari permintaan user dalam berkomunikasi antara partisipan

e. Membuat desain diagram kelas untuk masing-masing program aplikasi. Desain diagram kelas meliputi desain diagram kelas untuk aplikasi server, desain diagram kelas untuk aplikasi expert, dan desain diagram kelas untuk aplikasi client

f. Perancangan program aplikasi pelayanan vaksin online sebagai antarmuka bagi pengguna. Program aplikasi pelayanan vaksin online terdiri atas tiga bagian yaitu program aplikasi server, program aplikasi expert, dan program aplikasi client.

\section{Menentukan requirement sistem Pelayanan Vaksin Online}

Untuk merancang aplikasi Pelayanan Vaksin Online, maka beberapa aspek yang perlu dipahami dengan baik yaitu sifat komunikasi, model komunikasi, aktor-aktor yang berperan/tanggung jawab masing-masing aktor, tahapan prosedur/proses proses yang diperlukan dalam berkomunikasi, komponen-komponen protokol yang diperlukan untuk melakukan komunikasi, aturan-aturan spesifik yang diterapkan pada setiap layanan aplikasi komunikasi, dan desain antarmuka pengguna sebagai terminal komunikasi.

Aspek-aspek perancangan aplikasi Pelayanan Vaksin Online tersebut di atas merupakan suatu kesatuan dan pedoman untuk mengarahkan peneliti dalam tahapan pengembangan aplikasi Pelayanan Vaksin Online yang akan diuraikan berikut ini.

Requirement pelaksanaan pelayanan vaksin online melalui Internet:

a) pelayanan vaksin online diperlukan untuk melakukan komunikasi secara real time antara expert dan warga dalam pengurusan vaksin.

b) Komunikasi antara Pelayanan vaksin menggunakan media Internet.

c) Aplikasi Pelayanan berbasis web dapat mendukung komunikasi real time teks, unggah bahan dan koreksi dokumen.

d) Para expert dan warga wajib melakukan registrasi. Registrasi berfungsi sebagai identifier user untuk berbagai keperluan sepertilogin, identitas panggilan, informasi status user, pengaturan/pengendalian user untuk memperoleh kesempatan berkomunikasi bersama expert, komunikasi sesama dosen, dan identifier distribusi data aktual.

e) Para Expert dapat melakukan koreksi dan masukan secara langsung via online.

f) Pengiriman pesan dan data aktual melalui Internet dilakukan melalui dua proses utama yaitu proses pensinyalan untuk persetujuan komunikasi antara partisipan dan proses transportasi media data untuk pengiriman data aktual antara partisipan. 
g) Setiap user (warga) wajib melakukan login ke dalam sistem pelayanan vaksin online untuk verifikasi dan validasi pengguna. Setiap user wajib melakukan logout untuk keluar dari sistem seminar online. Logout berguna untuk memutuskan hubungan komunikasi antara partisipan dan update informasi status user.

\section{Identifikasi Aktor Pada Pelayanan Vaksin Online}

Peran dan tanggung jawab aktor yang terlibat dalam pelayanan vaksin online yaitu:

a) Aktor Administrator memiliki tugas mengelola semua akun dan mengatur serta memantau jalannya pelayanan vaksin online.

b) Aktor Expert memiliki tugas mengoreksi setiap pendaftaran yang masuk kedalam sistem

\section{Hasil dan Pembahasan}

\subsection{Analisa Sistem}

Pada rancangan sistem yang akan dibangun dalam penelitian ini menggunakan alat bantu perancangan sistem UML (Unified Modelling Language), Karena dengan UML lebih mudah untuk pengembangan sistem yang terintegrasi dan berulang, Sehingga sistem yang dibangun lebih terarah dan terkonsep dengan baik. Adapun data pengolahan pengurusan vaksin calon keberangkatan Jemaah umrah pada kantor kesehatan pelabuhan kelas II pekanbaru.

\subsection{Gambaran Sistem}

\subsubsection{Use Case Diagram Sistem Informasi Vaksin Online}

Adapun interaksi antara pengguna dengan sistem terlihat pada gambar 1.1 dibawah ini.

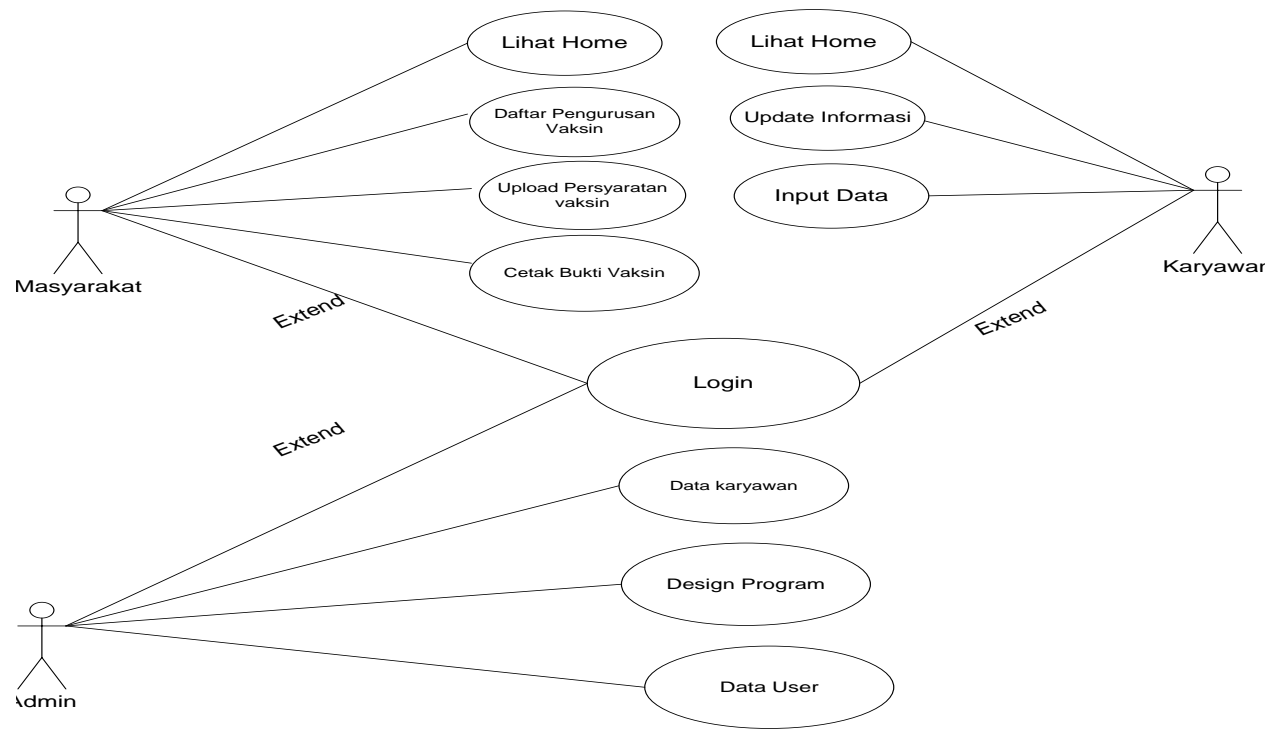

Gambar 1. Use Case Diagram sistem informasi

Pada usecase diagram sistem informasi berbasis online dalam pengurusan vaksin ada 3 aktor yaitu:

1. Admin bertugas sebagai operator program aplikasi untuk input dan mengelola data website

2. Karyawan bertugas sebagai menjadwalkan masyrakat yang akan mendaftar pengurusan vaksin 
3. Masyarakat yang mendaftar langsung kesistem berbasis online dalam pengurusan vaksin calon Jemaah umrah

\subsubsection{Activity Diagram Aplikasi Sistem Vaksin Online}

Bagan alir sistem aplikasi ini menjelaskan proses yang terjadi pada aplikasi yang dibuat secara keseluruhan. Pada bagan alir sistem aplikasi ini akan digambarkan bahwa data yang diinputkan pada aplikasi berasal dari satu sumber, yaitu dari harddisk ataupun media penyimpanan lainnya. Sebelum proses upload data, user harus memilih instruksi (menu) yang akan digunakan untuk memproses pengiriman data bahan. Bagan alir sistem pada halaman berikutnya.



Gambar 2. Activity Diagram sistem informasi

Diagram activity menggambarkan bagaimana kegiatan integrasi alur program pada pengurusan vaksin online calon keberanngkatan Jemaah umrah pada kantor kesehatan pelabuhan pekanbaru

\subsubsection{Class Diagram}

Adapun gambaran Class diagram pada penelitian ini dapat dilihat pada gambar 3 dibawah ini. 


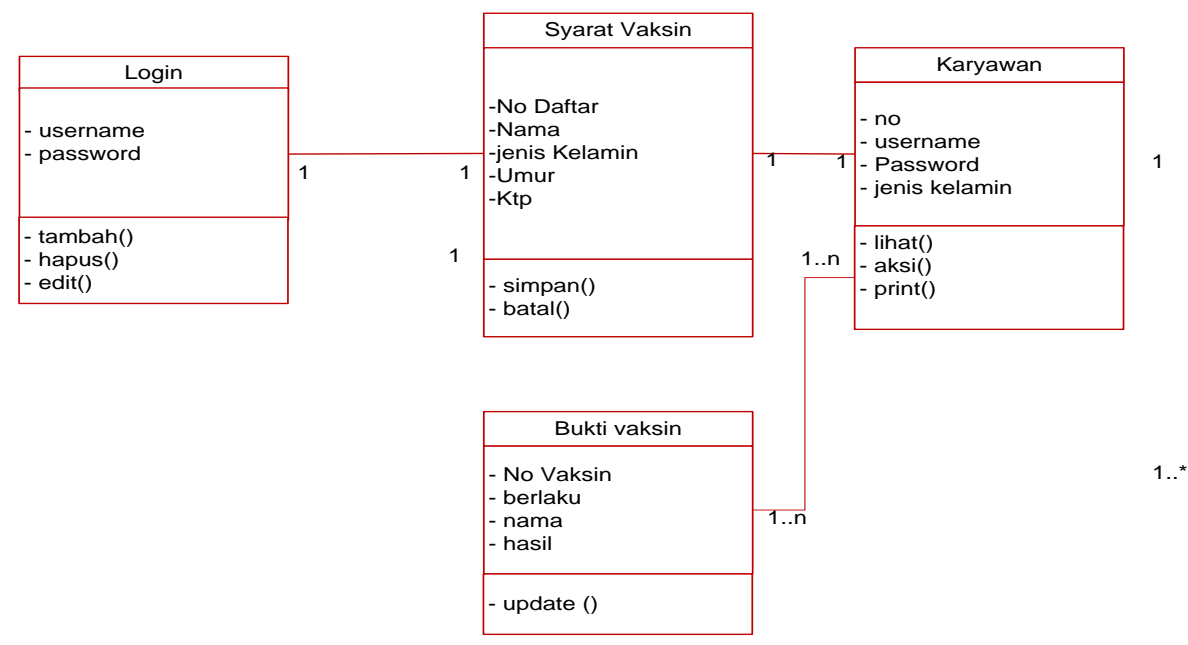

\section{Gambar 3. Class Diagram}

Diagram class menggambarkan bagaimana relasi data dan tabel yang berkaitan pada pengurusan vaksin online calon keberanngkatan Jemaah umrah pada kantor kesehatan pelabuhan pekanbaru

\subsection{Interface Sistem Informasi Pengurusan Vaksin Online}

Adapun hasil program dari penelitian ini dapat dilihat pada gambar dibawah ini.

\subsubsection{Menu Program}

Dalam perancangan program yang dibangun menu utama program dapat dilihat seperti gambardibawah ini.
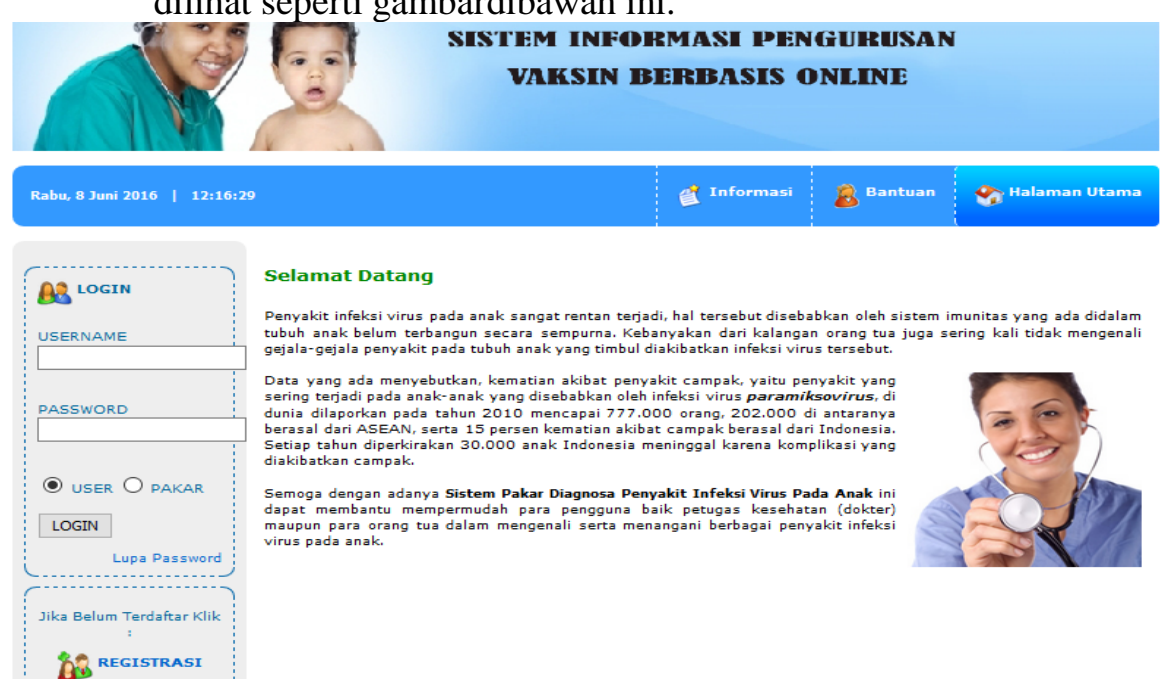

Gambar 4. Menu Program

\subsubsection{Upload Data}

Setelah mengisi username dan password pada menu program untuk masuk ke program untuk mengupload data bahan persyaratan dalam pengurusan vaksin calon keberangkatan jemaah umrah pada kantor kesehatan kelas II pekanbaru. 


\section{Kesimpulan}

Berdasarkan analisis dan pembahasan yang dilakukan, maka dapat disimpulkan Ada beberapa faktor yang menentukan dalam pengurusan vaksin online, Faktor yang mempengaruhi tersebut diperoleh dari beberapa pilihan yang diberikan sistem Efisiensi Peningkatan layanan vaksin Online belum bisa diukur karena belum adanya sosialisasi dalam pelatihan Penggunaan Aplikasi vaksin berbasis Online. Hasil dari penelitian model dari perancangan aplikasi dan aplikasi yang belum diimplementasikan pada kantor kesehatan Pelabuhan Sistem Informasi Berbasis Online yang dibangun menggunakan data yang ada pada kantor kesehatan pelabuhan kelas II pekanbaru.

\section{Daftar Pustaka}

[1] Hanson, 2000. Sejarah Pemograman berbasis Web. Yogyakarta: Andi offset

[2] Hardjono, 2006. Pengenalan Sistem Informasi Berbasis Web. Jakarta: Erlangga

[3] Kadir, Abdul. 2005. Pengenalan Sistem Informasi. Jakarta, Yogyakarta: Andi

[4] Nugroho, Andi.2004. Database Berbasis DBMS dalam Pengolahan Data Terintegrasi.

Bandung: Informatika

[5] Oneto, Erima. 2008. Cascadading Management Style Sebagai media Program Berbasis Web. Bandung: Informatika

[6] Sutabri, Tata. 2005. Sistem Informasi Managemen. Jakarta: Andi Jogja 